\title{
ADDITIONS TO THE LIST OF KANSAS ARACHNIDA.
}

By Theo. H. Scheffer, Manhattan.

T $\mathrm{N}$ his "Preliminary List of Kansas Spiders," published in vol. ume XIX of the Transactions of the Kansas Academy of Science, the writer recorded 100 species taken within the borders of the state, and expressed the desire to double the list in another season's collecting. But forty-three additional species of spiders have been taken, up to date, however. These are listed in the present paper, together with a preliminary report on other groups of the Arachnida represented in our state.

Four species of spiders new to science are described and figured in this paper. Several other single specimens probably represent new species, but it is not the policy of the writer to describe from a single specimen. To merit description, a supposedly new type should be fairly well represented in some locality.

The forty-three species herein listed represent eleven families and twenty-nine genera. Three of the families and seventeen of the genera were not included in the first list. All summed up, then, we have recorded from Kansas 143 species of spiders, representing 16 families and 67 genera.

The illustrations for this paper were by Miss Ella Weeks.

Types of the new species are in the Kansas Agricultural College collection and in the National Museum, at Washington.

ORDER ARANEIDA.

Family ATYPIDж.

Brachybothrum robustum Simon.

Brachybothrum robustum Simon. Actes Soc. Linn. Bord., vol. 44, p. 7. Two males from Manhattan, April 5, and an immature female from Delphos, August 5.

Family ULOBORID $Æ$.

Uloborus plumipes Lucas.

Uloborus plumipes Lucas. Explor. d'Algerie Anim., art. I, p. 252.

Two females taken in webs with cocoons at Manhattan, July 14. Immature male from St. George, June 6.

Hyptiotes cavatus Hentz.

Cyllopodia cavata Hentz. Jour. Bost. Soc. Nat. Hist., V, 1845, p. 466.

The Triangle spider is apparently rare in Kansas. A single specimen was found at Three-Mile Hill, near Manhattan, October 10. 
Family Tноміsid $Æ$.

Xysticus texanus Banks.

Xysticus texanus Banks. Journ. N. Y. Ent. Soc., XII, 1904, p. 112.

Two females of this prettily marked spider in a collection made at Delphos August 5.

Xysticus graminis Emerton.

Xysticus graminis Emerton. Trans. Conn. Acad., VIII, 1892, p. 364.

A male of this species from Manhattan, May 5.

Ebo latithorax Keyserling.

Ebo latithorax Keyserling. Neue Spinn. aus Amer., V, 1883, p. 678.

Adults of this species have not been observed, but the young were taken in considerable numbers in sweeping at Manhattan, October 11.

Philodromus rufus Walckenaer.

Philodromus rufus Walckenaer. Ins. Apt., I, 1837-'47, p. 555.

Several specimens collected at Minneapolis June 30.

Philodromoides, gen. nov.

Cephalothorax low, about as wide as long; head region much narrowed and slightly elevated. Abdomen fully twice as long as wide, very little wider behind than at the base; somewhat pointed at the end; the base projects a short distance over the cephalothorax, and is distinctly notched on the upper side. The sternum and labium are about as in Philodromus. All eyes approximately equal in size; the anterior row much the shorter and slightly recurved; median eyes of thịs row farther from each other than from the side eyes. Posterior row also recurved; side eyes of this row on larger tubercles than any of the others; median eyes farther from each other than from the side eyes. Ocular quadrangle considerably wider behind; about as wide as long. Clypeus wider than space between anterior median eyes, but not as wide as space between posterior median eyes; obliquely directed forward and downward. Legs long and slender, the second pair longest, the third shortest; the relative lengths are, in their order, second pair, first pair, fourth pair, third pair. The tibiæ of the first and second pairs are set beneath with ten or twelve stout spines arranged in two rows, and the metatarsi are similarly armed with half that number. Weaker spines likewise occur on the other two pairs of legs and on the pedipalps.

Philodromoides prataria, sp. nov. (fig. 10).

FEMALE.-Length, $6 \mathrm{~mm}$.; length and width of cephalothorax, $2 \mathrm{~mm}$.; width of abdomen, $2 \mathrm{~mm}$. Other characters as given in the generic description. A very few short, bristle-like hairs scattered about among the spines on the outer joints of the legs and on the cheliceræ and the pedipalps; thickest on the tarsi of the latter.

Coloration.-Abdomen plain brown above, mottled and streaked with a lighter shade. The four muscle impressions are quite distinct. Cephalothorax rusty brown, lighter at the sides and just back of the head region. Streaks marked by depressed lines radiate from the dorsal groove. The sternum is pale yellow or almost white. The abdomen is lighter beneath than above, and there is a less mottled central region, set off by a row of indistinct dots on either 
side. The legs are pale yellow to whitish. The femora, patellæ and tibiæ of all four pairs are marked in front with a longitudinal stripe of black, which becomes neatly obliterated on the metatarsi and tarsi. The corresponding joints of the legs of the third and fourth pairs are similarly marked on the hind border also. The males are somewhat smaller than the females, the abdomen being considerably narrower than the cephalothorax. The legs are more hairy in appearance and the spines less conspicuous than in the female. The color markings are about the same in the two sexes. This species is not uncommon about Manhattan, Kan., in midsummer. Mature males and females were taken in this locality on August 17.

\section{Family Clubionidæ.}

Castaneira crocata Hentz.

Herpyllus crocatus Hentz. Jour. Bost. Soc. Nat. Hist., V, 1845, p. 457.

Representatives of this species from Wallace, August 20, and from

Manhattan, July 29. From its general appearance and movements this spider might, at first sight, be easily mistaken for a velvet ant (mutillid).

Trachelas tranquilla Hentz.

Clubiona tranquilla Hentz. Jour. Bost. Soc. Nat. Hist., V, 1845, p. 450.

One female taken in collecting under stones at Lawrence October 8.

Zelotes decepta Banks.

\section{Family Drassid E.}

Prosthesima decepta Banks. Proc. Acad. Nat. Sci. Phila., 1900, p. 531.

A single male specimen from Manhattan, May 5.

Zelotes rufula Banks.

Prosthesima rufula Banks. Proc. Acad. Nat. Sci. Phila., 1892, p. 17.

A single female specimen from Manhattan, May 5.

Melanophora atra Hentz.

Herpyllus ater Hentz. Jour. Bost. Soc. Nat. Hist., V, 1845, p. 455.

Two females from Manhattan, May 1.

Gnaphosa sericata Koch.

Herpyllus bicolor Hentz. Jour. Bost. Soc. Nat. Hist., V, 1845, p. 456.

One female from Manhattan, July 27.

- Family SALticid

Phidippus pius, sp. nov. (figs. 1, 2, 7).

A medium-sized species, rather light in color. One male taken at Manhattan in October and two females in July.

Measurements. - Length of female, 9-10 $\mathrm{mm}$. Length of abdomen, $5 \mathrm{~mm}$; width of abdomen, $3 \mathrm{~mm}$. Width of cephalothorax about the same as that of abdomen. The measurements of the male are very approximately the same, except that the abdomen is slightly narrower.

LEgs. - Relative length, female, 4, 1, 2, 3; male, 1, 4, 2, 3. The legs of the first pair are considerably stouter than any of the others. First and second metatarsi set beneath with six stout spines in two rows. Tarsi of same legs with four spines. A few spines, less regularly placed, on the other legs also. 
CoLors. - Female pale yellow beneath, without markings. Very much the same above, except for a dark area occupying the ocellar quadrangle and two narrow, dark colored streaks, one on either side of the median line of the abdomen. The latter are not at all distinct on the anterior third of the abdomen. Two or more pairs of white spots dot these dark streaks. The ground color of the male is somewhat darker, shading into orange brown on the cephalothorax and legs. Like the female, the male is unmarked beneath and has, above, the two dark streaks on the abdomen and the dark area on the ocellar quadrangle. The femora and, to a certain extent, the other joints of all the legs are more or less streaked or almost banded with very dark brown. The tips of the tarsi in both sexes are dark. Palpal organs of the male dark except at the tip. Other joints of the palps pale and unmarked. The body and legs of both sexes are sparsely covered with long, silky hairs, with here and there a spine.

Phidippus texanus Banks.

Phidippus texanus Banks. Proc. Ent. Soc. Wash., 1905.

Not uncommon in the late summer and the autumn months. Specimens taken at Englewood and Medora in July, and at Manhattan in October.

Phidippus multiformis Emerton.

Phidippus multiformis Emerton. Trans. Conn. Acad., VIII, 1891, p. 6.

Two females and one male from Manhattan, July 27.

Phidippus montivagus Peckham.

Phidippus montivagus Peckham. Trans. Wis. Acad., XIII, p. 293.

A single specimen, female, from Manhattan, July 14.

Dendryphantes glacialis, sp. nov. (figs. 3, 4, 8).

An average-sized species, conspicuously striped on the abdomen. Two females were taken at Manhattan May 26, and a pair in the glacial region near St. George June 6.

Measurements. -Female, $5.5 \mathrm{~mm}$., male, $5 \mathrm{~mm}$. in length. Cephalothorax, $2.5 \mathrm{~mm}$. long, $2 \mathrm{~mm}$. wide.

Colors. - The cephalothorax of this species is reddish brown, with scattering white hairs thick enough at the sides and on the posterior slope to almost give the appearance of a band or stripe. About the eyes the red-brown is several shades darker. The ground color of the abdomen is dirty white tinged with yellow. Down the median line is a brown stripe, a little the wider in the male. On either side of this stripe is another of the same color and approximate width, curving a little to conform to the lateral border of the abdomen. Still another and wider stripe, not visible from a dorsal view, runs along each side of the abdomen. In the female this stripe is broken into spots or streaks. On the ventral surface there is a narrow median stripe from the genital opening to the spinnerets, and a wider stripe each side of this. The legs and palps are dull yellow tinged with brown, unmarked in the female, but much darker with some appearance of banding in the male. The front row of eyes is curved, with the middle eyes fully twice as large as the lateral, and almost as widely separated as the former and latter. 
Dendryphantes militaris Hentz.

Attus militaris Hentz. Jour. Bost. Soc. Nat. Hist., V, 1845, p. 201.

Not so common as D. capitatus. Specimens taken at Manhattan in October.

Pellenes cognatus Peckham.

Pellenes cognatus Peckham. Bull. Wis. Nat. Hist. Soc., I, 1901, p. 224.

One specimen, a female, from Arkalon, July 21.

Peckhamia picata Hentz.

Synemosyna picata Hentz. Jour. Bost. Soc. Nat. Hist., V, 1845, p. 370.

A pair of these ant-like spiders taken at Manhattan October 10. Neither sex was quite mature.

Mævia vittata Hentz.

Attus vittatus Hentz. Jour. Bost. Soc. Nat. Hist., V, 1845, p. 360.

Fairly common. Mature specimens taken at St. George June 6, and at Manhattan in October.

Thiodina sylvana Hentz.

Attus sylvanus Hentz. Jour. Bost. Soc. Nat. Hist., V, 1845, p. 364.

A male of this species from St. George, June 6.

Wala palmarum Hentz.

Epiblemum palmarum Hentz. Jour. Bost. Soc. Nat. Hist., V, 1845, p. 366.

Three males in material collected at Lawrence October 8.

Family ARGIOPIDж.

Araneus aculeatus Emerton.

Epeira aculeata Emerton. Bull. U. S. Geol. Surv. Terr., III, 1877, p. 528.

One specimen, a female, from Clark county, June 15.

Araneus trifolium Hentz.

Epeira trifolium Hentz. Jour. Bost. Soc. Nat. Hist., V, 1845, p. 471.

This large orb-weaver is represented in the college collection by a single specimen, female, taken at Manhattan August 22.

Araneus displicatus Hentz.

Epeira displicata Hentz. Jour. Bost. Soc. Nat. Hist., V, 1845, p. 476.

One male from St. George, June 6.

Araneus mormon Keyserling.

Epeira mormon Keyserling. Die Spin. Am., vol. IV.

A few specimens taken in provision stores of mud-dauber wasps at Meade July 18.

Acacesia foliata Hentz.

Epeira foliata Hentz. Jour. Bost. Soc. Nat. Hist., V, 1845, p. 475.

One female taken in sweeping at Lawrence September 8.

Mangóra placida Hentz.

Epeira placida Hentz. Jour. Bost. Soc. Nat. Hist., V, 1845, p. 475.

One female from Manhattan, May 2. Several males, lacking one moult of maturity, collected at Lawrence October 10.

Singa nigripes Keyserling.

Singa nigripes Keyserling. Verh. d. z. b. Ges. Wien, 1883, p. 655.

The species is fairly common in some localities. Specimens from St. George, June 6. 
Lycosa gracilis Banks.

\section{Family Lycosidæ.}

Lycosa gracilis Banks. Proc. Acad. Nat. Sci. Phila., 1892, p. 70.

A male from Manhattan, May 20.

Lycosa punctulata Hentz.

Lycosa punctulata Hentz. Jour. Bost. Soc. Nat. Hist., IV, 1842, p. 390.

A mature female of this moderately large species from Manhattan, October 6 .

Lycosa rufiventris Banks.

Lycosa rufiventris Banks. Proc. Acad. Nat. Sci. Phila., 1892, p. 65.

Not uncommon. Specimens taken at Manhattan in October and April. Lycosa permiana, sp. nov. (figs. 5, 6, 9).

A medium-sized spider, not uncommon in the spring and early summer. It hides among stones at some distance from watercourses.

Measurements. - Female, about $15 \mathrm{~mm}$. in length; male, 10-11 mm. Cephalothorax of female, $6 \mathrm{~mm}$. long, $4.5 \mathrm{~mm}$. wide; moderately arched, the highest point being about midway between the posterior eyes and the front of the dark line marking the dorsal groove. First leg, $14 \mathrm{~mm}$; fourth leg, $18 \mathrm{~mm}$.

Colors (in alcohol). - The ground color of both sexes is light yellow. In the male the abdomen is streaked and spotted with black above and brown below. In the female the similar markings of the abdomen are brown, both on the dorsal and the ventral surfaces. The ground color of the abdomen in this sex is sometimes more nearly dirty white than yellow. The markings of the cephalothorax are alike in the two sexes - a rich brown on the sides of the head and in the region traversed by the depressed lines radiating from the dorsal groove. The top of the head, or highest portion of the cephalothorax, is yellow. It is marked posteriorly by a pair of brown spots. A dark line marks the dorsal groove. The legs are light yellow, unmarked, but tinged with a suggestion of brown in places, especially on the distal joints. Numerous long, dark spines and a sparse covering of dark hairs tend to obscure the ground color of the legs. The coxæ and the sternum are brownish. The tarsi of the male palps are dark brown. Lycosids of this species collected at Manhattan in April and at Delphos in May. Both sexes mature at this time.

Pardosa texana Banks.

Pardosa texana Banks. Jour. N. Y. Ent. Soc., XII, 1904, p. 115.

One specimen, a female, from Englewood, August 8.

Pardosa milvina Hentz.

Lycosa milvina Hentz. Jour. Bost. Soc. Nat. Hist., IV, 1842, p. 392.

One lycosid of this species from Meade, July 18.

\section{Family AgELENID $\approx$.}

Cicurina arcuata Keyserling.

Cicurina arcuata Keyserling. Verh. d. z. b. Ges. Wien, 1887, p. 460.

Two specimens, a male and a female, taken at Manhattan, May 5.

Hahnia agilis Keyserling.

Hahnia agilis Keyserling. Verh. d. z. b. Ges. Wien, 1887, p. 465.

One specimen from Manhattan, April 15. 
Family Mimetid \&.

Mimetus interfector Hentz.

Mimetus interfector Hentz. Jour. Bost. Soc. Nat. Hist., VI, 1850, p. 32.

A female of this species taken in sweeping at Minneapolis June 30.

Family THERIDIID $A$.

Theridion puncto-sparsum Emerton.

Theridion puncto-sparsum Emerton. Trans. Conn. Acad., VI, 1882, p. 12.

Found occasionally at Manhattan. Specimens taken in July.

Theridion differens Emerton.

Theridion differens Emerton. Trans. Conn. Acad., VI, 1882, p. 9.

One specimen from Manhattan, May 26.

ORDER SCORPIONIDA.

Family CENTRURIDÆ.

Centrurus carolinianus Beauvois.

This seems to be the only species in the state. It is common under loose stones in limestone regions, and is less frequently met with under sandstone or loose bark in other localities. Specimens were taken at various times of the year in the following counties: Douglas, Pottawatomie, Riley, Ottawa, Russell, Smith, Clark, Barber, and Morton.

\section{ORDER PSEUDOSCORPIONIDA.}

Family ChELIFERIDA.

Chelifer cancroides Linnæus.

This species is found in almost any part of the United States. We have, in the college collection, specimens from Lawrence, Manhattan, and Sun. Most of them were taken under bark.

\section{ORDER SOLPUGIDA.}

\section{Family SolPUgID A.}

Eremobates pallipes Say.

These curious arachnids are not uncommon in the western and southwestern parts of the state. They are nocturnal in habit, and during the day are usually found under stones or cattle chips. Specimens have been secured in Wallace, Seward, Clark and Morton counties. But one Kansas species is known.

\section{ORDER PHALANGIDA.}

Liobunum vittatum Say.

Family Phalangid

Phalangium vittatum Say. Am. Ent., Lec. ed., vol. II, p. 13.

This is the common "daddy-long-legs" found in most parts of the United States. It includes Say's L. dorsatum, the more northerly type of the species. Abundant in the central and eastern portions of the state, but only occasionally met with in western and southwestern Kansas. Specimens from Delphos, Manhattan, and Lawrence, August to October. 
Trachyrhinus favosus Wood.

This species supplants L. vittatum in the southwestern part of the state. It frequents the sage-brush particularly, resembling this vegetation so closely in color that the collector is not likely to see it unless it is in motion. One specimen was taken at Manhattan, and numerous others at Englewood, Coldwater, Arkalon, and Sun, July to October.

Mesosoma niger Say.

Phalangium nigrum Say. Am. Ent., Lec. ed., vol. II, p. 14.

One specimen from Manhattan, October 15 . Others taken at Sun and Coldwater in the middle of July.

Cynorta sayii Simon.

Family Cosmetide.

Our representative of this family is fairly common in the eastern part of the state. It is the brownish-red phalangid, found singly, or, in the winter, in clusters under loose stones. Specimens collected at various times of the year in the vicinity of Manhattan, St. George, and Lawrence; one specimen from Sun.

\section{EXPLANATION OF FIGURES.}

Fig. 1. Phidippus pius. Female $\times 4$.

Fig. 2. Phidippus pius. Male $\times 4$.

Fig. 3. Dendryphantes glacialis. Male $\times 7$.

Fig. 4. Dendryphantes glacialis. Female $\times 7$.

Fig. 5. Lycosa permiana. Male $\times 3$.

Fig. 6. Lýcosa permiana. Female $\times 3$.

Fig. 7. Epigynum of Phidippus pius.

Fig. 8. Epigynum of Dendryphantes glacialis.

Fig. 9. Epigynum of Lycosa permiana.

Fig. 10. Philodromoides prataria. Female $\times 5$. 
Biologicaī Papers.

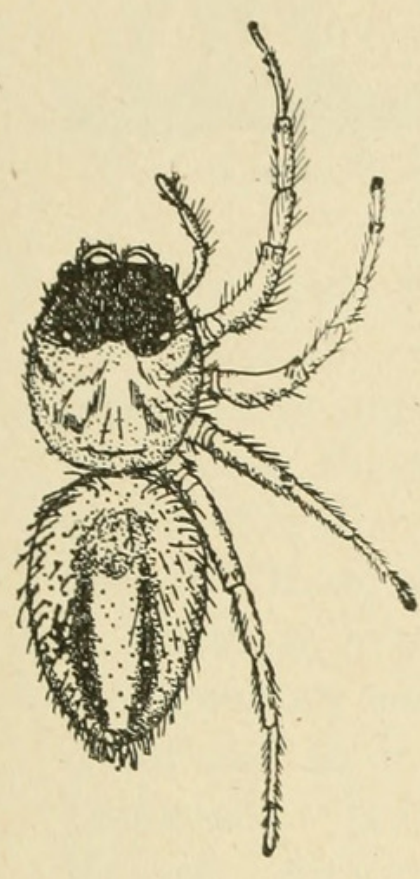

Fig. 1.

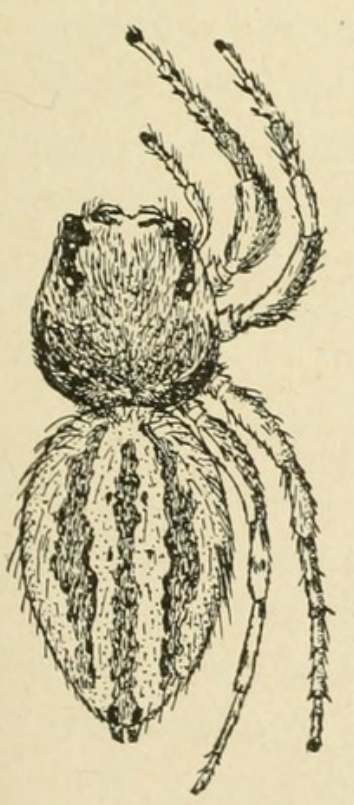

Fig. 4.

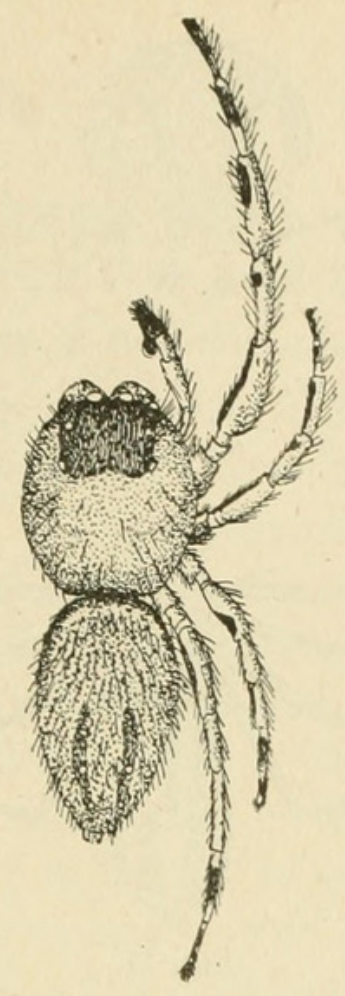

Fig. 2.

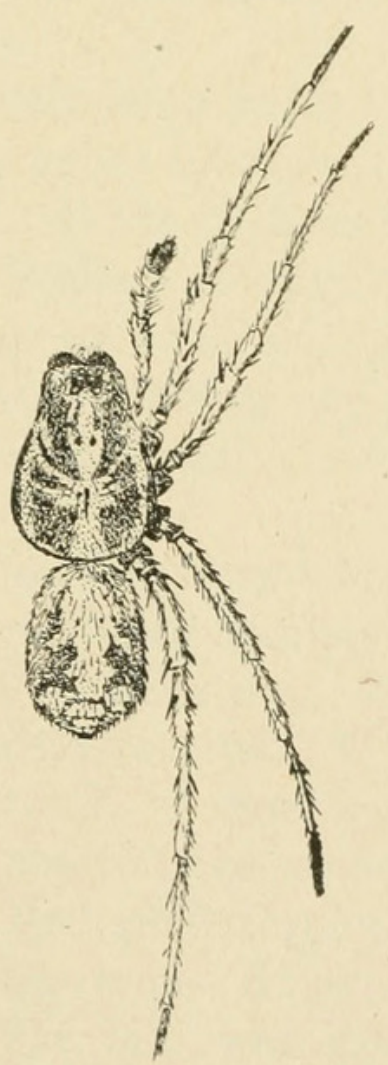

Fig. 5.

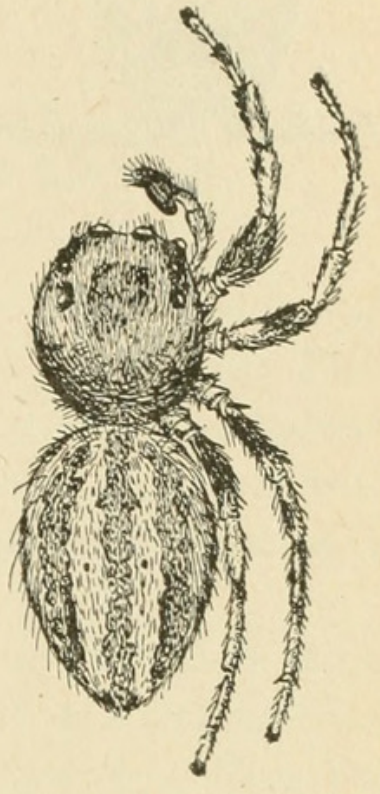

Fig. 3.

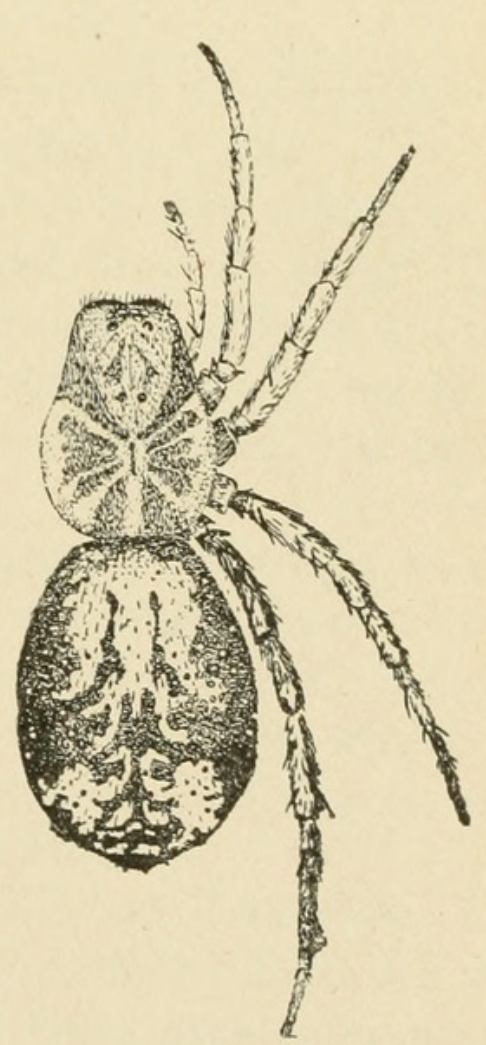

Fig. 6. 

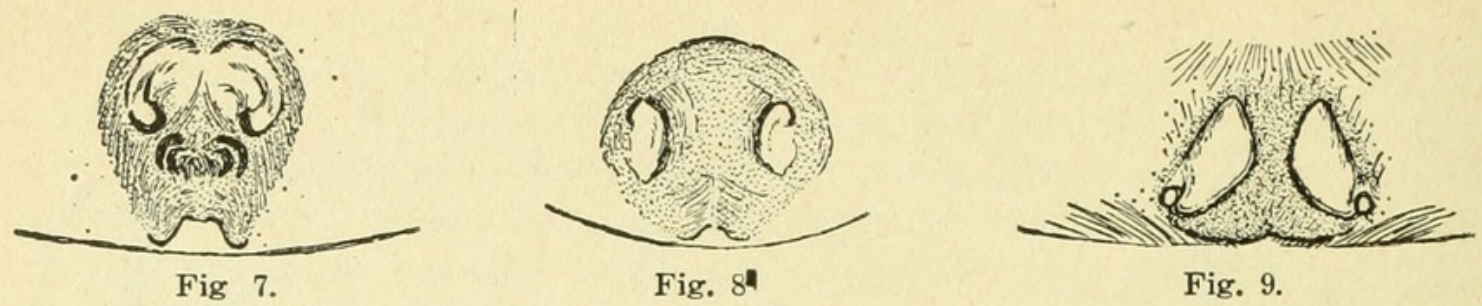

Fig. 9.

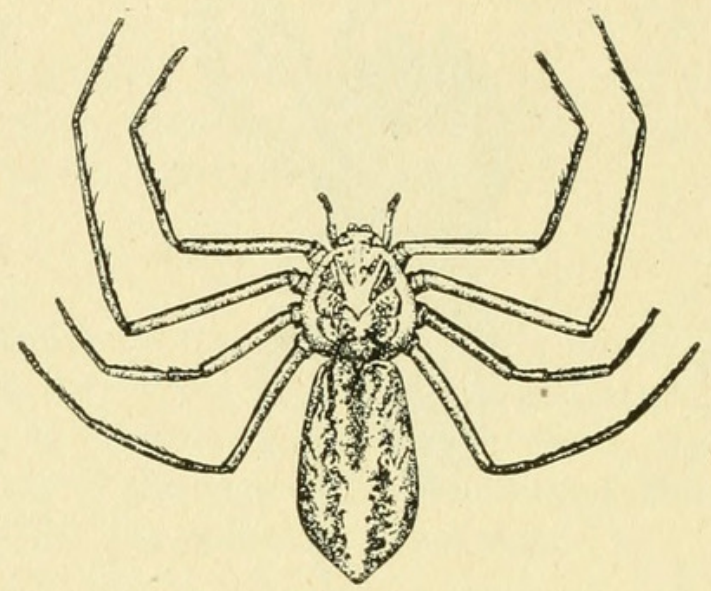

Fig. 10 . 


\section{$2 \mathrm{BHL}$ Biodiversity Heritage Library}

Scheffer, Theo. H. 1906. "Additions to the list of Kansas Arachnida." Transactions of the Kansas Academy of Science 20, 121-130.

View This Item Online: https://www.biodiversitylibrary.org/item/35329

Permalink: https://www.biodiversitylibrary.org/partpdf/2890

\section{Holding Institution}

Harvard University, Museum of Comparative Zoology, Ernst Mayr Library

\section{Sponsored by}

Harvard University, Museum of Comparative Zoology, Ernst Mayr Library

\section{Copyright \& Reuse}

Copyright Status: NOT_IN_COPYRIGHT

This document was created from content at the Biodiversity Heritage Library, the world's largest open access digital library for biodiversity literature and archives. Visit BHL at https://www.biodiversitylibrary.org. 